\title{
Analyzing the Relationship between Happiness, Teachers' Level of Satisfaction with Life and Classroom Management Profiles
}

\author{
Neslin İhtiyaroğlu \\ Faculty of Education, Kırıkkale University, Kırıkkale, Turkey
}

Copyright $\bigcirc 2018$ by authors, all rights reserved. Authors agree that this article remains permanently open access under the terms of the Creative Commons Attribution License 4.0 International License

\begin{abstract}
The purpose of this study is to determine the predictive role of happiness and a teachers' level of satisfaction with life, on their classroom management profiles. The Oxford Happiness Questionnaire Short Form, the Satisfaction with Life Scale, and the Classroom Management Profile Inventory have been administered to 384 teachers employed in state-run secondary education institutes in the districts of Ankara city. According to t-test results, there was a significant difference between the satisfaction with life and authoritarian classroom management profile, with respect to gender. One-way variance analysis (ANOVA) results exhibited that with respect to seniority no difference was detectable between happiness and a teachers' level of satisfaction with life and their classroom management profiles. Findings from a correlation analysis put forth a positive relationship between happiness and a satisfaction with life, and an appreciative classroom management profile, whereas a negative relationship was detected in relation to an indifferent classroom management profile. Findings from multiple regression analysis indicated that happiness and satisfaction with life are significant predictors of appreciative and indifferent classroom management profiles. At the end of this research some suggestions have been offered to elevate the happiness and satisfaction of teachers in general.
\end{abstract}

Keywords Teachers, Happiness Level, Satisfaction with Life, Classroom Management Profiles

\section{Introduction}

In-class attitudes and behaviors of teachers are among the most critical factors in creating permanent behavior changes among students, which is the ultimate objective of education. United around a common objective in a classroom, by teachers exemplifying a positive attitude and behavior, students can develop intellectually, psychologically, culturally, and shine as members of society. In order for teachers to provide favorable learning conditions in a classroom they should remove any blocks restricting learning and effectively channel available resources, students and manage the time to employ effective classroom management methods.

Classroom management can be defined collectively as; making essential shifts to meet the teachers objectives [1]; setting and maintaining a favorable environment for learning [2]; motivating the students and to reach preset objectives and incorporating these motivating materials into the process [3]; by connecting principles and rules in learning, and transferring effective teaching techniques to a classroom setting [4]; promoting a positive social interaction, active participation in learning and self-motivation [5]; in addition to the mission of teaching, managing areas such as absenteeism follow-up, checking homework, preparing teaching materials, and removing any factors blocking teaching activities [6].

Classroom management is a three-sided structure involving the individual, teaching and discipline [7]. On the individual side are the attitudes and behaviors of teachers towards their students, expectations from students, and the degree to which students can live up to these expectations. The teaching side calls for planning the activities, and organizing and setting time management. The discipline side involves the methods teachers use to help students adopt classroom rules. In the meta-analysis conducted by Marzano and Marzano [8] components of effective classroom management are listed as; identifying and teaching the rules, practicing feasible intervention techniques, as well as intellectual composition relevant to teacher-student interaction and classroom management.

Effective classroom management relies on factors inside and outside of a classroom setting. Factors outside of a class include course planning, the personal traits of teachers, a teacher-parent relationship, and psychological factors. On the other hand, in-class factors impact students' behavior and motivation; they define classroom rules and problems, effect in-class activities, teaching methods, and 
classroom management techniques [9]. Ineffective classroom management can easily turn the teaching process into chaos, and students can feel bored, confused or apathetic towards the course. That negativity can only be reversed once students form significant learning achievements, gain proficiency in the problem-solving process, and develop cooperative learning experiences with others [10]. Introducing such traits to students is closely linked with the classroom management skills of an involved teacher.

The classroom management skills of teachers call for competency in the field of study, purposeful behavior, in-class leadership, planning, in-class communication, in-class behavior management, activity management, time management and evaluation [11]. By embracing or dismissing these skills, teachers can perform a range of classroom management profiles in a classroom setting. These profiles can be categorized as authoritarian, appreciative, laissez faire, and indifferent classroom management styles. In an Authoritarian Classroom Management Profile, limitations and control mechanisms are used by teachers on the students. In an Appreciative Classroom Management Profile, the reasons for limitations and controls are explained to students, to support learner-autonomy and individuality. In a Laissez-faire Classroom Management Profile teachers assume the role of an observer and have very restricted expectations from their students. Students tend to behave the way they want. In an Indifferent Classroom Management Profile teachers have a lower level of participation in class activities and exhibit a higher level of indifferent behaviors [12].

Recent studies have examined the connection between the classroom management skills of teachers and their burnout level [13], work performance [14], job satisfaction, [15] and student success [16]; also the relationship between the interaction styles of teachers in classroom management, as well as students success rate, and positive classroom environment [17] have been analyzed; the relationship between personality types and classroom management profiles [18] have been examined; indifferent classroom management style and the correlation to stress level of teachers [19] have also been examined. These studies concluded that a range of variables interact with the classroom management skills of teachers. It is therefore suggested that classroom management profiles of teachers are likely to be impacted by their happiness and satisfaction with life.

In its generic definition Happiness is the level an individual perceives his/her life as positive. Four concepts being accentuated in this definition are; individual, subjectivity, perception and level. Happiness is a concept that is used to exhibit the current state of any individual. It is a subjective analysis of an individual's life. It is an intellectual activity formed by evaluating past experiences and estimating what the future can bring. It is expressed with both the minuteness and abundance of joy, and the level of its existence and absence. An individual can recognize his/her happiness by making a comparison with the times s/he is/was unhappy [20].

Although in relevant literature happiness is depicted as the state of subjective well-being [21] it entails a more generic meaning, than only subjective well-being [22]. Thus, happiness as a concept refers to an individual's sense of contentment in both cognitive and emotional dimensions [23]; domination of positive feelings in an individual's life and a low level of negative feelings [24]; a subjective evaluation process in which the criteria are determined by the concerned individual [25].

Happy individuals are more active, possess a higher number of friends, they can more easily accept or offer social support, they achieve successful long-term marriages, they have a high level of efficiency in their work life and achieve high-quality tasks, and they enjoy good physical health and maintain longer lives. In addition, happy individuals are more creative, they are more eager to help others and engage in charity events. They are moderately self-confident, self-controlled, organized and use effective coping strategies when stressed [26].

Relevant studies underlined the relationship between the level of happiness of an individual and their happiness level in a marriage [27]; social support and friendship [28]; life-quality [29]; satisfaction level with personal health [30]; group cooperation [31]; optimism level [32]; self-criticism level [33]; cognitive flexibility level; [34] and personality type [35]. There is also a long list of studies analyzing the relationship between the happiness level of an individual and their intention to quit a job [36]; job satisfaction [37; 38]; work performance [39]; income level [40]; corporate citizenship behaviors [41]; managerial evaluation [42]; sense of financial security; and job loyalty [43]. Based on all these studies it can be concluded that the happiness level of an individual is not only closely intertwined with variables affecting their life, but also with a number of variables related to their professional life. Hence it is safe to state that the happiness level of a teacher could be reflected in their classroom management profiles. Another variable considered to be potentially effective in classroom management profiles is satisfaction with life.

Based on a certain aspect of life that an individual likes or dislikes, their satisfaction with life can be defined by making an overall evaluation of his/her life [44]; an individual's cognitive assessment on the level of contentment with his/her life [45]; emotional reactions towards one's entire life including work life, free time and time outside of working hours [46]. Factors that play a role in satisfaction with life, are analyzed in four groups. These are personal factors, including variables such as an individual's age, gender, and educational level; environmental factors that relate to other work opportunities for an individual; social factors that are associated with the social relationships of an individual, family and friends; job-related factors that refer to an individual's career, work experience and salary [46].

Although satisfaction with life and happiness seem to be 
closely linked, they are two very different concepts. Happiness is an individual's self-evaluation of himself and his/her life in both a cognitive and emotional aspect [23]; on the other hand, satisfaction with life is an individual's self-perception of his/her quality of life with respect to specific criteria. Satisfaction with life is the relationship between an individual's desires and his/her current state. If a huge divergence is measured between the two, it is most likely that the satisfaction with life of an individual will be at a low level [47]. Living in a politically stable country, maintaining physiological and psychological wellness, having control over one's life, having a positive personality, enjoying a strong family and friendship bond as well as a wide social circle, and earning money, are some of the factors that can positively affect satisfaction in life [46].

Studies conducted showed ties between an individual's satisfaction with life and personality traits [48]; academic performance [49]; emotional intelligence [50] and intrinsic motivation [51]. Furthermore, a number of studies found connections between a teachers' satisfaction with life and job satisfaction [52]; organizational isolation level [53]; burnout Level [54], creativity, profundity, willingness for teamwork, level of forethought and appreciation [55]; and social support [56]. In light of these studies it can be assumed that a teachers' satisfaction with life is interlinked with a number of variables related to their professional life. Based on this finding it can also be claimed that a teachers' satisfaction with life would have an impact on their classroom management profiles.

Examining the relationship between happiness and teachers' satisfaction with life in their classroom management profiles, would play a vital role in discovering the effects of teachers' characteristics in their profession. Within that scope, the purpose of this study is to define the critical role of happiness and satisfaction, in the life of teachers in their classroom management styles. Within that context, the questions below should be answered:

1) What is the level of happiness of a teacher?

2) What is a teachers' level of satisfaction with life?

3) At what level are classroom management profiles of teachers?

4) Does a level of happiness, satisfaction with life, and the classroom management style of a teacher vary, with respect to gender and seniority at work?

5) Is there a significant relationship between happiness, teachers' satisfaction with life, and classroom management profiles?

6) Is a teachers' happiness and satisfaction with life significant predictor of their classroom management style?

\section{Materials and Methods}

This research, which examines the role of happiness and a teachers' satisfaction with life, on their classroom management profiles, is meant to be quantitative.

\subsection{Research Model}

In this study that has examined the predictive role of a teachers' happiness and satisfaction with life on their classroom management profiles, a relational screening model has been used. The relational screening model aims to determine concurrent changes between two and a higher number of variables, or it aims to measure the degree of this change (Karasar, 2006).

\subsection{Population and Sampling}

The research population consists of 9,228 teachers working in the state-run secondary education institutes, in the districts of Altındağ, Çankaya, Etimesgut, Sincan, and Yenimahalle, in Ankara, Turkey, for the 2016-2017 academic year. The research sampling consists of a selected 384 teachers from the population. Demographic of the teachers in the sampling are as displayed in Table 1:

Table 1. Demographic Features of Teachers

\begin{tabular}{|c|c|c|c|}
\hline \multicolumn{2}{|c|}{ Demographic Variables } & $\mathrm{n}$ & $\%$ \\
\hline \multirow{3}{*}{ Sex } & Female & 213 & 55 \\
\cline { 2 - 4 } & Male & 171 & 44 \\
\hline \multirow{4}{*}{ Seniority } & $1-10$ year & 154 & 40 \\
\cline { 2 - 4 } & $11-20$ year & 138 & 36 \\
\cline { 2 - 4 } & $21-30$ year & 74 & 19 \\
\cline { 2 - 4 } & 31-40 year & 18 & 5 \\
\hline
\end{tabular}

\subsection{Data Collection Tools}

To collect the data for the execution of this research, three measurement tools for teachers have been administered. These tools are Oxford Happiness Questionnaire Short Form developed by Hills and Argyle [57] and translated into Turkish by Doğan and Akıncı Çötok [58]; Satisfaction with Life Scale developed by Diener et al. [45] and translated into Turkish by Dağlı and Baysal [59]; Classroom Management Profile Inventory developed by Kris [60] and translated into Turkish by Ekici [12].

Oxford Happiness Questionnaire Short Form: The longer version of the original questionnaire consists of 29 items, while the shorter form includes 8 items. It is a 5 Likert-type scale scored between 1 (I completely disagree) and 5 (I completely agree). The correlation between the long and short form is at .93 level. In the Turkish-adapted version of the questionnaire, the internal consistency factor was measured as 0.74 ; test re-test reliability factor was detected to be 0.85 . Analyses of this research revealed that Cronbach's Alpha value equated to .91, whereas corrected items total correlation factors shifted between .32 and .49 . According to exploratory factor analysis, factor load values of items changed between .46 and .67 while the total variance explained is approximately $43 \%$. 
Satisfaction with Life Scale: This is 5-item scale with one factor. This 5 Likert-type scale is scored between 1 (I completely disagree) and 5 (I completely agree). In the Turkish adapted version of the scale, Pearson Product-Moment Correlation Coefficient was measured as .92; Cronbach Alpha internal consistency coefficient as .88 and test- retest reliability as .97 ; factor load values ranged from .73 to .89 . In this study Cronbach's Alpha value was measured as .93 , corrected item total correlation coefficients were seen to vary between .30 and .58 . Results of exploratory factor analysis showed that factor load values of items changed between .61 and .83 and total variance explained is around $62 \%$.

Classroom Management Profile Inventory: This inventory consists of four dimensions comprising a total of 12 items; Authoritarian Classroom Management profile (3 items), Appreciative Classroom Management profile (3 items), Laissez faire Classroom Management profile (3 items), and Indifferent Classroom Management profile (3 items). It is a 5 Likert-type scale scored between 1 (I completely disagree) and 5 (I completely agree). Cronbach Alpha reliability value of the overall scale equated to 0.85 ; as for its sub dimensions Authoritarian Classroom Management profile value was measured as .80, Appreciative Classroom Management profile value as .79, Laissez faire Classroom Management profile value as .82, and Indifferent Classroom Management profile value as .81. In this scale positive factor analysis was employed to determine validity of the scale, and accordingly the findings were such; RMSEA $=.006, \mathrm{CFI}=.94, \mathrm{GFI}=.92$. These findings suggest that the scale can be sufficiently explained under four sub sections and correlation between the items is in an acceptable range. In addition, internal consistency coefficients measured for dimensions of the scale are; for the Authoritarian Classroom Management profile .78, for the Appreciative Classroom Management profile .81, for the Laissez faire Classroom Management profile .83 , and for the Indifferent Classroom Management profile it is .76 .

\subsection{Data Analysis}

Data collected from administered scales were tested by t-test, which is one of the parametric tests, one-way variance analysis (ANOVA), correlation and regression analyses, and SPSS 20 software program. In this study, it has been identified that there was a correlation between the t-test, the one-way variance analysis (ANOVA), and teachers with happy and satisfying lives, and their classroom management profiles with respect to variables such as gender and seniority. Correlation analysis was then employed to exhibit the level and direction of the relationship between a teachers' happiness level, their satisfaction with life and their classroom management profiles. Regression analysis was harnessed to determine the predictive role of a teachers' happiness and satisfaction with life, on their classroom management profiles.

\section{Findings}

In this section findings collected at the end of this study are demonstrated as parallel sub headings, with research questions. In the first part are the mean and standard deviation values of the level of a teachers' happiness, satisfaction with life, and classroom management style; next findings about the relationship of a teachers' happiness level, satisfaction with life level, and their classroom management profiles with respect to gender and seniority. In the second part, findings on the relationship between happiness level, satisfaction with life level, and the classroom management profiles of teachers have been presented; subsequently findings in relation to the predictive role of a teachers' happiness and satisfaction their classroom management profiles, have been demonstrated.

\subsection{Mean and Standard Deviation Values of the Variables and Findings, on the Relationship of Variables, with Respect to Gender and Seniority Factors}

In Table 2, mean and standard deviation values of the variables are exhibited:

Table 2. Mean and Standard Deviation Values of the Variables

\begin{tabular}{|c|c|c|c|}
\hline Variables & $n$ & $\bar{X}$ & $S$ \\
\hline Happiness & 384 & 3.77 & 1.28 \\
\hline Satisfaction With Life & 384 & 4.12 & 2.47 \\
\hline $\begin{array}{c}\text { Authoritarian Classroom } \\
\text { Management Profile }\end{array}$ & 384 & 3.11 & .56 \\
\hline $\begin{array}{c}\text { Appreciative Classroom } \\
\text { Management Profile }\end{array}$ & 384 & 4.20 & .52 \\
\hline $\begin{array}{c}\text { Laissez Faire Classroom } \\
\text { Management Profile }\end{array}$ & 384 & 2.10 & .57 \\
\hline $\begin{array}{c}\text { Indifferent Classroom } \\
\text { Management Profile }\end{array}$ & 384 & 1.92 & .56 \\
\hline
\end{tabular}

As seen in Table 2 the variable with the highest mean score is satisfaction with life $(\bar{x}=4.12)$. With regards classroom management profiles, appreciative classroom management profile $(\bar{X}=4.20)$ and authoritarian classroom management profile $(\bar{X}=3.11)$ are the two variables with the highest mean score. Laissez faire Classroom Management profile $(\bar{X}=2.10)$ and indifferent classroom management profiles $(\bar{x}=1.92)$ are the variables with the lowest mean score. In Table 3, it is viable to determine mean and standard deviation values of happiness and satisfaction with life, as well as classroom management profiles of teachers, by gender. In addition, the table displays t-test results that exhibit the relationship of these variables with gender: 
Table 3. Mean, Standard Deviation an t-test Values of Variables with respect to Gender

\begin{tabular}{|c|c|c|c|c|c|c|}
\hline Variables & Sex & $n$ & $\bar{X}$ & $S$ & $t$ & $p$ \\
\hline \multirow{2}{*}{ Happiness } & Female & 213 & 3.81 & 1.28 & \multirow{2}{*}{3.58} & \multirow{2}{*}{.64} \\
\hline & Male & 171 & 3.72 & 1.27 & & \\
\hline \multirow{2}{*}{$\begin{array}{l}\text { Satisfaction with } \\
\text { Life }\end{array}$} & Female & 213 & 4.36 & 2.47 & \multirow{2}{*}{2.76} & \multirow{2}{*}{.00} \\
\hline & Male & 171 & 3.86 & 2.47 & & \\
\hline \multirow{2}{*}{$\begin{array}{l}\text { Authoritarian } \\
\text { Classroom } \\
\text { Management } \\
\text { Profile }\end{array}$} & Female & 213 & 2.94 & 0.55 & \multirow[b]{2}{*}{1.12} & \multirow[b]{2}{*}{.01} \\
\hline & Male & 171 & 3.27 & 0.56 & & \\
\hline \multirow{2}{*}{$\begin{array}{l}\text { Appreciative } \\
\text { Classroom } \\
\text { Management } \\
\text { Profile }\end{array}$} & Female & 213 & 4.16 & 0.52 & \multirow[b]{2}{*}{1.23} & \multirow[b]{2}{*}{.28} \\
\hline & Male & 171 & 4.23 & 0.52 & & \\
\hline \multirow{2}{*}{$\begin{array}{l}\text { Laissez Faire } \\
\text { Classroom } \\
\text { Management } \\
\text { Profile }\end{array}$} & Female & 213 & 2.21 & 0.57 & \multirow[b]{2}{*}{2.11} & \multirow[b]{2}{*}{.39} \\
\hline & Male & 171 & 1.99 & 0.56 & & \\
\hline \multirow{2}{*}{$\begin{array}{l}\text { Indifferent } \\
\text { Classroom } \\
\text { Management } \\
\text { Profile }\end{array}$} & Female & 213 & 1.78 & 0.56 & \multirow[b]{2}{*}{1.79} & \multirow[b]{2}{*}{.17} \\
\hline & Male & 171 & 2.06 & 0.56 & & \\
\hline
\end{tabular}

As demonstrated in Table 3, with respect to gender, among the female teachers there is higher level of relationship between mean scores of happiness $(\bar{X}=3.81)$ and satisfaction with life $(\bar{X}=4.36)$ and laissez faire classroom management profile $(\bar{X}=2.21)$, when compared to the mean scores of male teachers; as for male teachers it can be seen that mean scores of authoritarian $(\bar{X}=3.27)$, appreciative $(\bar{X}=4.23)$ and indifferent $(\bar{X}=2.06)$ classroom management profiles, were higher than the mean scores of female teachers. With respect to gender there was not a significant difference ( $p>.05)$ detected between a teachers' happiness and satisfaction with life, and the appreciative, laissez faire and indifferent classroom management profiles. Despite that, the authoritarian classroom management profile $(p<.05)$ of teachers significantly varied by gender. The authoritarian classroom management profile mean score of male teachers, is above the mean score of female teachers. In Table 4 ANOVA results provide the relationship between a teachers' happiness, satisfaction with life level, and classroom management profile, by seniority:

Table 4. ANOVA results of Variables by Seniority

\begin{tabular}{|c|c|c|c|c|c|c|c|c|c|c|c|}
\hline \multirow[t]{2}{*}{ Variables } & \multicolumn{2}{|c|}{$\begin{array}{l}1-10 \text { year } \\
(154)\end{array}$} & \multicolumn{2}{|c|}{$\begin{array}{l}11-20 \text { year } \\
\quad(138)\end{array}$} & \multicolumn{2}{|c|}{$\begin{array}{l}21-30 \text { year } \\
(74)\end{array}$} & \multicolumn{2}{|c|}{$\begin{array}{l}\text { 31-40 year } \\
\quad(18)\end{array}$} & \multirow[t]{2}{*}{$F$} & \multirow[t]{2}{*}{$p$} & \multirow[t]{2}{*}{$\begin{array}{l}\text { Sig } \\
\text { Dif }\end{array}$} \\
\hline & $\bar{x}$ & $S$ & $\bar{x}$ & $S$ & $\bar{x}$ & $S$ & $\bar{x}$ & $S$ & & & \\
\hline Happiness & 3.98 & 1.27 & 3.82 & 1.28 & 3.71 & 1.28 & 3.45 & 1.28 & 4.89 & .73 & \\
\hline Satisfaction with Life & 4.31 & 2.47 & 4.22 & 2.47 & 4.08 & 2.46 & 4.01 & 2.46 & 6.87 & .22 & \\
\hline $\begin{array}{l}\text { Authoritarian Classroom Management } \\
\text { Profile }\end{array}$ & 2.91 & .55 & 2.98 & .56 & 3.12 & .56 & 3.21 & .56 & 1.54 & .57 & \\
\hline $\begin{array}{c}\text { Appreciative Classroom Management } \\
\text { Profile }\end{array}$ & 4.26 & .52 & 4.11 & .52 & 4.27 & .52 & 4.08 & .53 & 1.23 & .69 & \\
\hline $\begin{array}{l}\text { Laissez Faire Classroom Management } \\
\text { Profile }\end{array}$ & 1.93 & .56 & 2.01 & .56 & 2.17 & .57 & 2.21 & .57 & 1.90 & .85 & \\
\hline Indifferent Classroom Management Profile & 1.59 & .56 & 1.69 & .56 & 2.14 & .56 & 2.17 & .56 & 1.45 & .11 & \\
\hline
\end{tabular}

Table 4 exhibits that as the seniority level increases, a decrease was measured in a teachers' happiness and satisfaction with life. In the happiness and satisfaction with life level, the highest mean score was measured in seniority of 1-10 years $(\bar{X}=3.98, \bar{X}=4.31)$; the lowest mean score was measured in seniority of $31-40$ years $(\bar{X}=3.45, \bar{X}=4.01)$. As for classroom management profiles, the seniority level with the highest score was in the authoritarian classroom management profile and the mean score corresponded to 31-40 years $(\bar{X}=3.21)$; the lowest mean score was measured in seniority of 1-10 years $(\bar{X}=2.91)$. As for Appreciative Classroom Management profile the highest mean score was measured in seniority of $1-10$ years $(\bar{X}=4.26)$; the lowest mean score was seen in seniority of $31-40$ years $(\bar{X}=4.08)$. In Laissez faire and indifferent classroom management profiles, a rise in seniority level corresponded to an increase in adopting such styles. Among these profiles the seniority year with the lowest mean score was $1-10$ years $(\bar{X}=1.93, \bar{X}=1.59)$; the highest mean score was measured in 31-40 seniority years $(\bar{X}=2.21, \bar{X}=2.17)$. It is also evidenced that with respect to seniority level, teachers' Happiness and Satisfaction with Life level and authoritarian, appreciative, laissez faire, and indifferent classroom management profiles, did not vary $(\mathrm{p}>.05)$.

\subsection{Relationships between a Teachers' Happiness and Satisfaction with Life Level, and their Classroom Management Profiles}

In Table 5 the findings from the correlation analysis conducted to identify the relationships between a teachers' Happiness and Satisfaction with life level and classroom management profiles, are exhibited. 
Table 5. Relationships between Variables

\begin{tabular}{|c|c|c|c|c|c|c|}
\hline Variables & 1 & 2 & 3 & 4 & 5 & 6 \\
\hline 1. Happiness & 1 & $.68 * *$ & $.04 *$ & $.49 * *$ & $-.11 *$ & $-.32 * *$ \\
\hline $\begin{array}{l}\text { 2. Satisfaction } \\
\text { with Life }\end{array}$ & & 1 & $.12 *$ & $.57 * *$ & $-.03 *$ & $-.37 * *$ \\
\hline $\begin{array}{c}3 . \\
\text { Authoritarian } \\
\text { Classroom } \\
\text { Management } \\
\text { Profile } \\
\end{array}$ & & & 1 & $.36 * *$ & $-.47 * *$ & $-.42 * *$ \\
\hline $\begin{array}{l}\text { 4. Appreciative } \\
\text { Classroom } \\
\text { Management } \\
\text { Profile }\end{array}$ & & & & 1 & $-.29 * *$ & $-.10 *$ \\
\hline $\begin{array}{l}\text { 5. Laissez Faire } \\
\text { Classroom } \\
\text { Management } \\
\text { Profile }\end{array}$ & & & & & 1 & $.31 * *$ \\
\hline $\begin{array}{l}\text { 6. Indifferent } \\
\text { Classroom } \\
\text { Management } \\
\text { Profile }\end{array}$ & & & & & & 1 \\
\hline
\end{tabular}

Table 5 displays that among these variables, the highest relationship exists between Happiness and Satisfaction with life level $(r=.68 ; p<.01)$. In addition, a positive relationship existed between the Happiness and Satisfaction with life level and the Appreciative Classroom Management profile $(r=.49, \quad r=.57 ; p<.01)$ and the Authoritarian Classroom Management profile $(r=.04$, $r=.12 ; p<.05)$; however, a negative relationship was detected among the Happiness and Satisfaction with Life level and the Indifferent Classroom Management profile $(r=-.32, r=-.37 ; p<.01)$ and the Laissez faire Classroom Management profile $(r=-.11, r=-.03 ; p<.05)$. As for classroom management profiles, a positive relationship was detected between the Authoritarian Classroom Management profile and the Appreciative Classroom Management profile $(r=.36 ; p<.01)$ as well as between the Laissez faire Classroom Management profile and the Indifferent Classroom Management profile $(r=.31 ; p<.01)$; yet negative relationships were observed between the Authoritarian Classroom Management profile and the Appreciative Classroom Management profile, as well as the Laissez faire Classroom Management profile $(r=-.47$, $r=-.29 ; p<.01)$, and the Indifferent Classroom Management profile $(r=-.42, p<.01 ; \quad r=-.10, \mathrm{p}<.05)$.

\subsection{Findings on the Predictive Role of a Teachers' Happiness and Satisfaction with Life Level, on their Classroom Management Profiles}

In parallel with the sub problem of this research; Is a Teachers' Happiness and Satisfaction with life level a significant predictor of their classroom management style? the results of a progressive regression analysis conducted to reveal the predictive role of a teachers' Happiness and Satisfaction with life level, on their classroom management styles can be observed in Table 6:

Table 6. The Results of Progressive Regression Analysis

\begin{tabular}{|c|c|c|c|c|c|c|c|c|c|c|}
\hline $\begin{array}{l}\text { Classroom } \\
\text { Management } \\
\text { Profile }\end{array}$ & Model & Predictors & $B$ & $S E$ & $\beta$ & $t$ & $p$ & $R$ & $R^{2}$ & Std. Error \\
\hline \multirow{5}{*}{$\begin{array}{l}\text { Authoritarian } \\
\text { Classroom } \\
\text { Management } \\
\text { Profile }\end{array}$} & \multirow{2}{*}{1} & Constant & 34.98 & 2.19 & & 12,65 & .23 & \multirow{2}{*}{.04} & \multirow{2}{*}{.027} & \multirow{2}{*}{10.34} \\
\hline & & Happiness & .09 & 0.6 & .04 & 3,70 & .11 & & & \\
\hline & \multirow{3}{*}{2} & Constant & 27.77 & 4.97 & & 7,43 & .19 & \multirow{3}{*}{.09} & \multirow{3}{*}{.031} & \multirow{3}{*}{10.76} \\
\hline & & Happiness & .06 & .07 & .03 & 2.49 & .22 & & & \\
\hline & & Satisfaction with Life & .17 & .08 & .09 & 4.28 & .27 & & & \\
\hline \multirow{5}{*}{$\begin{array}{l}\text { Appreciative } \\
\text { Classroom } \\
\text { Management } \\
\text { Profile }\end{array}$} & \multirow{2}{*}{1} & Constant & 28.96 & 3.17 & & 17.69 & .00 & \multirow{2}{*}{.49} & \multirow{2}{*}{.486} & \multirow{2}{*}{10.20} \\
\hline & & Happiness & .33 & 0.7 & .56 & 11.32 & .00 & & & \\
\hline & \multirow{3}{*}{2} & Constant & 26.61 & 5.63 & & 9.51 & .00 & \multirow{3}{*}{.53} & \multirow{3}{*}{.517} & \multirow{3}{*}{10.12} \\
\hline & & Happiness & .32 & .07 & .51 & 6.97 & .00 & & & \\
\hline & & Satisfaction with Life & .38 & .08 & .58 & 4.12 & .00 & & & \\
\hline \multirow{5}{*}{$\begin{array}{l}\text { Laissez Faire } \\
\text { Classroom } \\
\text { Management } \\
\text { Profile }\end{array}$} & \multirow{2}{*}{1} & Constant & 22.16 & 4.21 & & 13,14 & .14 & \multirow{2}{*}{-.11} & \multirow{2}{*}{.012} & \multirow{2}{*}{9.96} \\
\hline & & Happiness & -.15 & 0.7 & -.16 & $-5,26$ & .12 & & & \\
\hline & \multirow{3}{*}{2} & Constant & 23,58 & 6.28 & & 7,51 & .13 & \multirow{3}{*}{-.07} & \multirow{3}{*}{.017} & \multirow{3}{*}{9.25} \\
\hline & & Happiness & -.14 & .07 & -.21 & $-3,67$ & .15 & & & \\
\hline & & Satisfaction with Life & -.17 & .08 & -.12 & $-3,27$ & .17 & & & \\
\hline \multirow{5}{*}{$\begin{array}{l}\text { Indifferent } \\
\text { Classroom } \\
\text { Management } \\
\text { Profile }\end{array}$} & \multirow{2}{*}{1} & Constant & 17.25 & 3.28 & & 15,89 & .00 & \multirow{2}{*}{-.32} & \multirow{2}{*}{.372} & \multirow{2}{*}{11.16} \\
\hline & & Happiness & -.28 & 0.7 & -.37 & $-9,71$ & .00 & & & \\
\hline & \multirow{3}{*}{2} & Constant & 18.32 & 5.27 & & 8,43 & .00 & & & \\
\hline & & Happiness & -.24 & .07 & -.32 & $-7,09$ & .00 & -.36 & .411 & 11.31 \\
\hline & & Satisfaction with Life & -.31 & .08 & -.40 & $-7,81$ & .00 & & & \\
\hline
\end{tabular}


Table 6 demonstrates that in the first model related to the Authoritarian Classroom Management profile, teachers' Happiness level has a weak and insignificant relationship with the Authoritarian Classroom Management profile $(R$ $\left.=.04 ; R^{2}=.03 ; p>.01\right)$. A Happiness level explains $02.7 \%$ of total variance of the Authoritarian Classroom Management profile. In the second model, next to the happiness variable, the satisfaction with life variable has been included in the model and an explained variance increased from $2.7 \%$ to $3.1 \%$. This finding reveals that satisfaction with life contributed a level of $0.4 \%$ to the explained variance. According to standardized regression coefficient $(\beta)$ a weak but positive and significant relationship existed between happiness level (.03) and satisfaction with life (.09) and authoritarian classroom management profile. On the other hand, findings of $t$-test on the significance of regression coefficients reveal that a rise in the Happiness and Satisfaction with life level, had no predictive role on the Authoritarian Classroom Management profile ( $p>.01)$.

In the first model displayed in Table 6 , on the relationship with the Appreciative Classroom Management profile, it is seen that a high level and significant relationship existed between a teachers' happiness level and the Appreciative Classroom Management profile $(R$ $\left.=.49 ; R^{2}=49 ; p<.01\right)$. Happiness level explains $48.6 \%$ of the total variance of the Appreciative Classroom Management profile. In the second model, next to the happiness variable, the satisfaction with life variable has been included in the model and an explained variance increased from $48.6 \%$ to $51.7 \%$. This finding suggests that satisfaction with life contributed to the explained variance by a level of $3.1 \%$. In terms of standardized regression coefficient $(\beta)$ predictive variables' order of significance on the Appreciative Classroom Management profile, is ordered as Satisfaction with life (.58) and Happiness levels (.51). Results of $t$-test related to the significance of regression coefficients prove that Happiness and Satisfaction with life levels have a predictive role on the Appreciative Classroom Management profile $(p<.01)$.

In the first model explained in Table 6 on the relevance of the Laissez faire Classroom Management profile, it can be detected that a teachers' happiness level has a weak and insignificant relationship with the Laissez faire Classroom Management profile $\left(R=-.11 ; R^{2}=.01 ; p>.01\right)$. Happiness level explains $1.2 \%$ of the total variance of the Laissez faire Classroom Management profile. In the second model, in addition to the Happiness variable, the Satisfaction with life variable was included in the model, and the explained variance climbed from $1.2 \%$ to $1.7 \%$. This finding evidences that satisfaction with life contributed to the explained variance by a level of $0.5 \%$. According to standardized regression coefficient $(\beta)$ a weak but negative and significant relationship existed between the happiness level $(-.21)$ and the satisfaction with life $(-.16)$ and the Laissez faire Classroom Management profile. According to the results of $t$-test on the significance of regression coefficients, happiness and satisfaction with life level have no predictive role on the laissez faire classroom management profile $(p>.01)$.

In the first model displayed in Table 6 on the indifferent classroom management profile it was seen that a positive and significant relationship existed between a teachers' Happiness level and the Indifferent Classroom Management profile $\left(R=-.32 ; R^{2}=.37 ; p<.01\right)$. Happiness level explains $37.2 \%$ of the total variance of the indifferent classroom management profile. In the second model next to the Happiness variable, the satisfaction with life variable has been included in the model thus the explained variance rose from $37.2 \%$ to $41.1 \%$. This finding proves that Satisfaction with life contributed to the explained variance by a level of $3.9 \%$. According to standardized regression coefficient $(\beta)$ predictive variables' order of insignificance on the indifferent Classroom Management profile, is as in the order of the Satisfaction with life (-.40) and the Happiness levels (-.32). Results of $t$-test on the significance of Regression coefficients demonstrate that the Happiness and Satisfaction with life levels are significant predictors of the Indifferent Classroom Management profile $(p<.01)$.

\section{Discussion}

In this study of the relationship of a Teachers' Happiness and Satisfaction with life level with their classroom management profile, it has been ascertained that a teachers' satisfaction with life is one variable with the highest mean score, and that the most popular profiles among teachers are appreciative and authoritarian classroom management profiles. A teachers' Happiness and Satisfaction with life level is above the average score. According to the Satisfaction with life Survey conducted annually since 2003, a vast majority of Turkish citizens enjoy a happiness level with an above average score [61]. In a study conducted by Düzgün [62] a teachers' happiness level and in Demirel's [63] research a teachers' satisfaction with life level, were observed to be above average score. Studies conducted revealed that the most popular profile was the Appreciative Classroom Management profile among teachers $[12 ; 64 ; 65]$, while the second ranking was for the authoritarian classroom management profile [18]. The studies mentioned are in parallel with the findings of the mean scores of variables in this study.

In this study it was observed that teachers with a Happiness Level and an appreciative, a laissez faire and an indifferent classroom management profile, varied insignificantly by gender. On the other hand, there was a differentiation by gender between teachers in regards to the satisfaction with life level and the Authoritarian Classroom Management profile. Studies show that between a teachers' happiness level [66;67] and an appreciative [65], a laissez faire and an indifferent classroom management profiles $[68 ; 12 ; 65]$, there was no differentiation with respect to the gender. However, satisfaction with life $[69 ; 54 ; 70]$ and the authoritarian classroom management profiles $[68 ; 12]$ 
varied by gender. In the satisfaction with life, female teachers' mean score was above the male teachers' mean score, this can be explained that social relations take the front stage [71] among women, and teaching is a profession with an accentuated social dimension. In the Authoritarian Classroom Management profile, the male teachers' mean scores were above the female teachers, and this can be attributed to the notion that men pay more heed to cognitive actions, such as success and intellectual stamina, whereas women care more about emotional traits such as love and intimate relations [72].

Another finding of this study is that a teachers' Happiness and Satisfaction with life level, as well as classroom management profiles did not vary with respect to professional seniority. Yet when a teachers' mean scores from Happiness and Satisfaction with life are analyzed with respect to seniority, it is seen that in both dimensions the highest mean score corresponded to the first years of their profession, between 1-10 years. As the professional seniority year of a teacher climbed, it is noted that both Happiness and Satisfaction with Life level decreased. In parallel with the climb in teachers' professional seniority, there is a decrease in their Happiness and Satisfaction with life level. In addition, mean scores of teachers in the laissez faire and the indifferent classroom management profiles do jump, as their seniority level increases. That is to say, teachers who adopt a less indifferent and laissez faire Classroom Management profile during the early years in the profession, tend to adopt these profiles more frequently as their seniority rises. This finding is attributable to the notion that as a teachers' seniority climbs there is a corresponding increase in their professional burnout [73] and indifference level. Heightened burnout level and a sense of indifference [74] could have an adverse effect on their happiness and satisfaction with life level, thereby potentially triggering them to adopt a heightened laissez faire and indifferent attitude.

In this study, the highest relationship was observed between a teachers' happiness and satisfaction with life level. This finding echoes the research results of Murat and Demir [67]. Diener [25] in his study explained that one of the three components of happiness is satisfaction with life. The other two components are affective dimension, and as for satisfaction with life, it points to the cognitive dimension. Thus, a significant relationship between happiness and satisfaction with life can be explained with the notion that satisfaction with life is the cognitive dimension of happiness [25]. In addition, the strong relationships between happiness and satisfaction with life and classroom management profiles, exhibited a positive link with an appreciative classroom management profile, but a negative association with an indifferent classroom management profile. Based on the notion that feelings cause motivational force for individuals and behaviors play a shaping role [75], teachers with a high level of Happiness and Satisfaction with life opt for the Appreciative
Classroom Management profile, which is one of the positive classroom management profiles. However, teachers with low level of happiness and satisfaction with life, more frequently employ the indifferent management profile which is among the negative classroom management profiles.

It has been concluded in this study that Happiness and Satisfaction with life are significant predictors of the appreciative and the indifferent classroom management profiles. Adopting an Appreciative Classroom Management profile reveals that teachers enjoy higher levels of happiness and satisfaction with life, while adopting the Indifferent Classroom Management profile may be attributed to the low Happiness and Satisfaction with life level of the said teachers. Studies conducted indicate that relationships existed between a teachers' happiness level and job satisfaction [76], optimism level [67], and work life quality [77]. Also, certain connections were exhibited with respect to satisfaction with life level and attitudes towards the teaching profession [70], burnout level [54], and problem-solving skills [78]. As one of the predictive results of this study supported by the abovementioned researches it is safe to argue that a teachers Happiness and Satisfaction with life, plays role in a wide array of organizational and behavior variables. A high level of Happiness and Satisfaction with life among teachers, motivates them to adopt positive organizational behaviors, whereas a low level of Happiness and Satisfaction with life may lead to negative organizational behaviors.

\section{Conclusion and Suggestions}

To sum up in this study that designated the predictive role of a teachers' Happiness and Satisfaction with life level on their classroom management profiles, satisfaction with life was found to be the variable with the highest mean score. Teachers most frequently adopted the Appreciative Classroom Management profile. Yet teachers had a lower tendency to employ the laissez faire and the indifferent classroom management profiles, which are among the negative classroom management profiles. With respect to gender, not a significant difference was seen between a teachers' happiness level and an appreciative, a laissez faire and an indifferent classroom management profile; however, satisfaction with life level and an authoritarian classroom management profile, varied with respect to gender. In addition, a teachers' Happiness and Satisfaction with life level, as well as their classroom management profiles did not vary with respect to seniority. The highest relationship among all variables was measured between Happiness and Satisfaction with life. On the other hand, a positive link was measured between Happiness and Satisfaction with life and the appreciative Classroom Management profile, while a negative relationship was detected with the Indifferent Classroom Management profile. Happiness and 
Satisfaction with life were significant predictors of the appreciative and the indifferent classroom management profiles, but they had no such predictive role on the authoritarian and the laissez faire classroom management profiles.

Since Happiness and Satisfaction with life had a positive predictive role on the appreciative Classroom Management profile, which is a positive classroom management profile, and a negative predictive role on the Indifferent Classroom Management profile, which is among the negative Classroom Management profiles, in order for teachers to become happy individuals with high satisfaction with life they are recommended to ignite self-actualization process as individuals. In this process the critical steps to take would be recognition of oneself by teachers, by exploring their personal traits, the strong and weak aspects, and by receiving professional help if needed at the very beginning. Furthermore, it is particularly recommended that teachers attend informative programs on self-awareness during the process of self-actualization. It is also suggested that policy makers value and support specific methods and tools in order to fulfill the physiological and wellbeing of teachers who are at the first steps of the self-actualization process. As the initial planner of the school environment, it is proposed that principals secure a positive school environment, thereby supporting a teachers' need of belonging. Teachers' classroom management styles cannot only be affected by personal variables such as happiness and satisfaction with life, but also by a school climate and the behavior of colleagues and administrators. Within that context, it is suggested that researchers conduct future studies to analyze the relationship between classroom management styles and the abovementioned variables, so that a positive effect can be provided to analyze the very same issue from a multidimensional perspective.

\section{Acknowledgements}

A part of this study was presented as oral presentation in $8^{\text {th }}$ International Educational Forum, October 19-21, TOBB Economics and Technology University: Ankara, Turkey.

\section{REFERENCES}

[1] Şişman, M. (1999). Öğretmenliğe giriş. Ankara: Pegem A.

[2] Erdoğan, İ. (2002), Sınıf yönetimi. İstanbul: Sistem.

[3] Celep, C. (2002). Sinıf yönetimi ve disiplini. Ankara: An1

[4] Özel, A., \& Bayındır, N. (2008). Yapılandırmacı anlayışa göre sinıf yönetimi. Ankara: Pegem A.

[5] Burden, P. R. (2003). Classroom management: Creating a successful learning community. New York, USA: John
Wiley \& Sons Publishing.

[6] Demirel, Ö. (1999). Öğretme sanat: Plandan değerlendirmeye. Ankara: Pegem A.

[7] Martin, N., \& Baldwin, B. (1993). An examination of the construct validity of the inventory of classroom management style. Paper presented at the Annual Conference of the Mid-South Educational Research association, New Orleans, LA. Retrieved in 2018 from: http://eric.ed.gov/ERICDocs/data/ericdocs 2 sql/content_sto rage_01/0000019b/80/15/30/70.pdf

[8] Marzano, R. J., \& Marzano, J. S. (2003). The key to classroom management. Educational Leadership, 61(1), 6-18.

[9] Spahiu, I., \& Spahiu, E. (2013). Teachers role in classroom management and traditional methods. Anglisticum Journal, 2(3), 91-100.

[10] Snowman, J., \& McCown, R. (2012). Psychology applied to teaching. Canada: Cengage Learning.

[11] Çubukçu, Z., \& Girmen, P. (2008). Öğretmenlerin sınıf yönetimi becerilerine ilişkin görüşleri. Bilig / Türk Dünyası Sosyal Bilimler Dergisi, 44, 123-142.

[12] Ekici, G. (2004). İlköğretim I. kademe öğretmenlerinin sınıf yönetimi profillerinin değerlendirilmesi. Eğitim ve Bilim, $131,50-60$

[13] Yıldırım, U. (2016). Sınıf öğretmenlerinin tükenmişlik düzeyi ile sinıf yönetimi arasındaki ilişki. Unpublished master's dissertation, İstanbul Aydın University, Social Sciences Institution, İstanbul, Turkey.

[14] Sönmez, E. (2014). İlk ve ortaokullardaki öğretmenlerin sınıf yönetimi becerileri ile performansları arasındaki ilişki. Unpublished master's dissertation, Kastamonu University, Social Sciences Institution, Kastamonu, Turkey.

[15] Akın, U., \& Koçak, R. (2007). The relationship between teachers' classroom management skills and job satisfaction. Educational Administration: Theory and Practice, 51, 353-370

[16] Adeyemo, A. S. (2012). The relationship between effective classroom management and students' academic achievement. European Journal of Educational Studies 4(3), 367-381.

[17] Djigić, G. \& Stojiljković, S. (2011). Classroom management styles, classroom climate and school achievement. Procedia - Social and Behavioral Sciences, 29, 819-828 doi:10.1016/j.sbspro.2011.11.310

[18] Kurt, H., Ekici, G., Aksu, Ö. ve Aktaş, M. (2013) Öğretmen adaylarının kişilik tipleriyle sınıf yönetimi profilleri arasındaki ilişkisinin değerlendirilmesi. Ĕgitim ve Öğretim Araştırmaları Dergisi, 2(2), 189-198.

[19] Hoots, S. (2014). The relationship between classroom management, coping styles, and stress. Unpublished master's dissertation, Eastern Illinois University, Education Sciences Institution, Illinois.

[20] Veenhoven, R. (2009). How do we assess how happy we are? In A. Dutt, A. Dutt, \& B. Radcliff (Eds.), Happiness, economics and politics (pp. 45-69). USA: Edward Elger Publishers. 
[21] Öztürk, A., \& Cetinkaya, R. S. (2015). Eğitim fakültesi öğrencilerinin öznel iyi oluş düzeyleri ile tinsellik, iyimserlik, kaygı ve olumsuz duygu düzeyleri arasındaki ilişki. Marmara Üniversitesi Ĕ̈itim Bilimleri Dergisi, 42, 145-166 doi: 10.15285/ebd. 98899

[22] Nordenfelt, L. (1993). Quality of life, health and happiness. Aldershot: Avebury.

[23] Diener, E., \& Diener, C. (1996). Most people are happy. Psychological Science, 7(3), 181-184 doi: 10.1111/ j.1467-9280.1996.tb00354.x

[24] Myers, D. G., \& Diener, E. (1995). Who is happy? Psychological Science, 6(1), 10-19 doi: 10 1111/j.1467-9280.1995.tb00298.x

[25] Diener, E. (1984). Subjective well-being. Psychological Bulletin, 95(3), 542-575 doi: 10.1037/0033-2909. 95.3.542

[26] Lyubomirsky, S., King, L. A., \& Diener, E. (2005). The benefits of frequent positive affect. Psychological Bulletin, 131, 803-855 doi: 10.1037/0033-2909.131.6. 803

[27] Glenn, N. D., \& Weaver, C. N. (1979). A note on family situation and global happiness. Social Forces, 57(3), 960-967 doi: $10.2307 / 2577364$

[28] Baldassare, M., Rosenfield, S., \& Rook, K. S. (1984). The types of social relations predicting elderly well-being. Research on Aging, 6, 549-559.

[29] Collins, J. E., Hanson, K., Mulhern, M., \& Padberg, R. M. (1992). Sense of coherence over time in cancer patients: A preliminary report. Medical Psychotherapy, 5, 73-82.

[30] Lyubomirsky, S., Tkach, C., DiMatteo, M. R., \& Lepper, H. S. (2006). What are the differences between happiness and self-esteem? Social Indicators Research, 78, 363-404 doi: 10.1007/s11205- 005-0213-y.

[31] Barsade, S. G., Ward, A. J., Turner, J. D. F., \& Sonnenfeld, J. A. (2000). To your heart's content: A model of affective diversity in top management teams. Administrative Science Quarterly, 45, 802-836 doi: 10.2307/2667020.

[32] Sapmaz, F., \& Doğan, T. (2012). İyimserliğin mutluluk ve yaşam doyumuna etkisinin incelenmesi. Mersin Üniversitesi Ë̆itim Fakültesi Dergisi, 8(3), 63-69.

[33] Doğan, T., Sapmaz, F., \& Akıncı Çötok, N. (2013). Öz-eleştiri ve mutluluk. Kastamonu Eğitim Dergisi, 21(1), 391-400

[34] Asıc1, E., \& İkiz, F. B. (2015). Mutluluğa giden bir yol: Bilișsel esneklik. Mehmet Akif Ersoy Üniversitesi Eğitim Fakültesi Dergisi, 35, 191 -211.

[35] Pishva, N., Ghalehban, M., Moradi, A., \& Hoseini, L. (2011). Personality and happiness. Procedia-Social and Behavioral Sciences, 30, 429-432 doi: 10.1016/j.sbspro.2011.10.084

[36] Gil, K. M., Carson, J. W., Porter, L. S., Scipio, C., Bediako, S. M., \& Orringer, E. (2004). Daily mood and stress predict pain, health care use,mand work activity in African American adults with sickle cell disease. Health Psychology, 23, 267-274 doi: 10.1037/0278-6133.23.3.267

[37] Donovan, M. A. (2000). Cognitive, affective, and satisfaction variables as predictors of organizational behaviors: A structural equation modeling examination of alternative models. Dissertation Abstracts International, 60(9-B), 4943. (UMI No. AAI9944835)

[38] Weiss, H. M., Nicholas, J. P., \& Daus, C. S. (1999). An examination of the joint effects of affective experiences and job beliefs on job satisfaction and variations in affective experiences over time. Organizational Behavior and Human Decision Processes, 78, 1-24 doi: 10.1006/obhd.1999.2824

[39] DeLuga, R. J., \& Mason, S. (2000). Relationship of resident assistant conscientiousness, extraversion, and positive affect with rated performance. Journal of Research in Personality, 34, 225-235 doi: 10.1006/ jrpe.1999.2272

[40] [40] Lucas, R. E., Clark, A. E., Georgellis, Y., \& Diener, E. (2003). Reexamining adaptation and the set point model of happiness: Reactions to changes in marital status. Journal of Personality and Social Psychology, 84, 527-539 doi: 10.1037/0022-3514. 84.3.527

[41] Miles, D. E., Borman, W. E., Spector, P. E., \& Fox, S. (2002). Building an integrative model of extra role work behaviors: A comparison of counterproductive work behavior with organizational citizenship behavior. International Journal of Selection and Assessment, 10, 5157 doi: 10.1111/1468-2389.00193

[42] Cropanzano, R., \& Wright, T. A. (1999). A 5-year study of change in the relationship between well-being and job performance. Consulting Psychology Journal: Practice and Research, 51, 252-265 doi: 10.1037/1061-4087.51.4.252

[43] Roberts, B. W., Caspi, A., \& Moffitt, T. E. (2003). Work experiences and personality development in young adulthood. Journal of Personality and Social Psychology, $84,582-593$ doi: $10.1037 / / 0022-3514.84 .3 .582$

[44] Heller, D., Judge, T. A. ve Watson, D. (2002). The confounding role of personality and trait affectivity in the relationship between job and life satisfaction, Journal of Organizational Behavior, 23, 815-835 doi: 10.1002/job. 168

[45] Diener, E., Emmons, R. A., Larsen, R. J. ve Griffin, S. (1985). The satisfaction with life scale. Journal of Personality Assessment, 49(1), 71-75 doi: 10.1207/ s15327752jpa4901_13

[46] Özdevecioğlu, M., \& Aktaş, A. (2007). Kariyer Bağlılığ1, Mesleki bağlılık ve örgütsel bağlılığın yaşam tatmini üzerindeki etkisi: İș-aile çatıșmasının rolü. Erciyes Üniversitesi İktisadi ve İdari Bilimler Fakültesi Dergisi, 28, $1-20$.

[47] Pavot, W., \& Diener, E. (1993) Review of the Satisfaction with Life Scale. Psychological Assessment, 5, 164-172 doi: 10.1007/978-90-481-2354-4 5,

[48] Schimmack, U., Oishi, S., Furr, R. M., \& Funder, D. C. (2004). Personality and life satisfaction: A facet-level analysis. Personality and Social Psychology Bulletin, 30, 1062-1075 doi: 10.1177/0146167204264292

[49] Antaramian, S. (2017). The importance of very high life satisfaction for students' academic success. Cogent Education, 4(1), 1-10. doi: 10.1080/2331186x. 2017.1307622e

[50] Özyer, K., Azizoğlu, Ö., \& Fahreeva, G. (2011). A study 
about relationship between emotional intelligence and life satisfaction. Akademik Bakış Dergisi, 25, 1-20.

[51] Mafini, C., \& Dlodlo, N. (2014). The relationship between extrinsic motivation, job satisfaction and life satisfaction amongst employees in a public organisation. SA Journal of Industrial Psychology, 40(1), 1-13. doi: 10.4102/ sajip.v40i1.1166

[52] Erdamar, G., \& Demirel, H. (2016). Job and life satisfaction of teachers and the conflicts they experience at work and at home. Journal of Education and Training Studies, 4(6), 164-175 doi: 10.11114/ jets.v4i6.1502

[53] Deveci Sirin, H., \& Sirin, E. F. (2015). The relationshıp between life satisfaction levels and work alienation in physical education teachers. Asian Journal of Instruction, $3(2), 1-14$.

[54] Özyürek, A., Gümüş, H., \& Doğan, S. (2012). Öğretmen ve okul yöneticilerinin tükenmişlik ve yaşam doyumunun incelenmesi. International Journal of Human Sciences [Online] 9(2), 892-904.

[55] Abasimi, E., \& Xiaosong, G. (2016). Character strengths and life satisfaction of teachers in Ghana. Humanities and Social Sciences Letters, 4(1), 22-35 doi: 10.18488/journal.73/2016.4.1/73.1.22.35

[56] Hasan, I., Batool. T., \& Fatima, S. (2015). Life satisfaction and social support among private and government school teachers. European Journal of Business and Social Sciences, 4(8), 100-105 doi:10.18488/journal.73/2016.4.1/73.1.22.35

[57] [57] Hills, P., \& Argyle, M. (2002). The Oxford Happiness Questionnaire: A compact scale for the measurement of psychological well-being. Personality and Individual Differences, 33, 1073-1082 doi: 10.1016/S0191-8869 (01)00213-6.[58]

[58] Doğan, T. ve Akınc1-Çötok, N. (2011). Oxford Mutluluk Ölçeği Kısa Formunun Türkçe uyarlaması: Geçerlik ve güvenirlik çalışması. Türk Psikolojik Danışma ve Rehberlik Dergisi, 4(36), 165-172.

[59] Dağl1, A., \& Baysal, N. (2016). Yaşam doyumu ölçeğinin Türkçe 'ye uyarlanması: Geçerlik ve güvenirlik çalışması. Elektronik Sosyal Bilimler Dergisi, 15(59), 1250-1262.

[60] Kris, B. (1996). Teacher talks "what is your classroom management profile?" http://education.ndiana.edu /cas/ $\mathrm{tt} / \mathrm{v} 1 \mathrm{i} 2 /$ what. html.

[61] Türkiye İstatistik Kurumu (2016). Yaşam memnuniyeti araştırması. Retrieved from http:// www.tuik.gov.tr/ PreHaberBultenleri.do?id=24641

[62] Düzgün, O. (2016). Ortaokulda görev yapmakta olan ögretmenlerin mutluluk düzeyleri ile sinıf yönetimi becerileri arasındaki ilișki. Unpublished Master Dissertation. Gaziosmanpaşa Üniversitesi, Eğitim Bilimleri Enstitüsü, Tokat.

[63] Demirel, H. (2014). An investigation of the relationship between job and life satisfaction among teachers. Social and Behavioral Sciences, 116, 4925-4931.

[64] Ekici, G., Aluçdibi, F., \& Öztürk, N. (2012). Biyoloji öğretmenlerinin sınıf yönetimi profillerinin cinsiyet ve kıdem değişkenleri açısından incelenmesi. Dicle Üniversitesi Sosyal Bilimler Enstitüsü Dergisi, 4 (8), 13-30.

[65] Yılmaz, K. (2011). İlköğretim okulu öğretmenlerinin sınıf yönetimi tarzları ile demokratik değerlere ilişkin görüşleri arasındaki ilişki. Değerler Ĕgitimi Dergisi, 9(21), 147-170.

[66] Buragohain, P., \& Hazarika, M. (2015). Happiness level of secondary school teachers in relation to their job satisfaction. SSRG International Journal of Humanities and Social Science, 2(3), 19-37.

[67] Demir, R., \& Murat, M. (2017). Öğretmen adaylarının mutluluk, iyimserlik, yașam anlamı ve yaşam doyumlarının incelenmesi. OPUS Uluslararast Toplum Araştırmalart Dergisi, 7(13), 347-378 doi: 10.26466/opus.347656

[68] Çiftçi, A. S. (2015). İlkokul öğretmenlerinin sinıf yönetim tarzlarl ve demokratik değerlere ilișkin görüşleri arasındaki ilişki. Unpublished master's dissertation, Çanakkale Onsekiz Mart University, Education Sciences Institution, Çanakkale, Turkey.

[69] Okursoy, F. T. (2016). Öğretmenlerin özyeterlik algılart ile yaşam doyumlarl arasındaki ilişki. Master Project. Pamukkale University, Education Sciences Institution, Denizli, Turkey.

[70] Recepoğlu, E. (2013). Öğretmen adaylarının yaşam doyumları ile öğretmenlik mesleğine ilişkin tutumları arasındaki ilișkinin incelenmesi. Hacettepe Üniversitesi Eğitim Fakültesi Dergisi, Özel sayı (1), 311-326.

[71] Meggiolaro, S., \& Ongaro, F. (2013). Life satisfaction among the elderly in Italy in a gender approach. Ageing and Society 35(07), 1-24 doi: 10.1017/S0144686X 14000646

[72] Rokeach, M. (1973). The nature of human values. New York: The Free Press.

[73] Öktem, E. (2009). İlköğretimde görev yapan öğretmenlerin tükenmişlik düzeylerinin bazı değişkenlere göre incelenmesi (Afyonkarahisar-Sandıklı örneği). Unpublished master's dissertation, Ege University, Social Sciences Institution, İzmir, Turkey.

[74] Cemaloğlu, N., Şahin D.E. (2007). Öğretmenlerin mesleki tükenmişlik düzeylerinin farklı değişkenlere göre incelenmesi. Kastamonu Eğitim Dergisi, 15(2), 465-484.

[75] Ekman, P. (1994). All emotions are basic. E. P. Derl, J. R Davidson (Eds.). The Nature of Emotion: Fundamental Questions. New York-Oxford University Press.

[76] Terzi, S. (2017). Öğretmenlerin iş doyumları ile mutluluk düzeyleri arasındaki ilişkinin incelenmesi. 21. Yüzyılda Eğitim ve Toplum, 6, 475-487.

[77] Toulabi, Z., Raoufi, M., \& Allahpourashraf, Y. (2013). The relationship between teachers' happiness and quality of working life. Procedia-Social and Behavioral Sciences, 84, 691-695 doi: 10.1016/j.sbspro.2013. 06.628

[78] Kabasakal, Z. ve Uz-Baş, A. (2013). Öğretmen adaylarında yaşam doyumunun yordayıcısı olarak problem çözme becerileri. Ĕ̌itim ve Öğretim Araştırmaları Dergisi, 2(1), 27-35. 